\title{
Impact of Population and Latrines on Fecal Contamination of Ponds in Rural Bangladesh
}

\author{
Peter S. K. Knappett ${ }^{1,{ }^{*}, \text { Veronica Escamilla }}{ }^{2,3}$, Alice Layton ${ }^{4}$, Larry D. McKay ${ }^{1}$, Michael \\ Emch $^{2,3}$, Daniel E. Williams ${ }^{4}$, Md. R. Huq ${ }^{5}$, Md. J. Alam ${ }^{5}$, Labony Farhana ${ }^{5}$, Brian J. \\ Mailloux ${ }^{6}$, Andy Ferguson ${ }^{7}$, Gary S. Sayler ${ }^{4}$, Kazi M. Ahmed ${ }^{5}$, and Alexander van Geen ${ }^{8}$ \\ ${ }^{1}$ Department of Earth and Planetary Sciences, The University of Tennessee, Knoxville, TN \\ 37996-1410 \\ ${ }^{2}$ Department of Geography, University of North Carolina - Chapel Hill, NC 27599-3220 \\ ${ }^{3}$ Carolina Population Center, University of North Carolina - Chapel Hill, NC 27516-2524 \\ ${ }^{4}$ Center for Environmental Biotechnology, The University of Tennessee, Knoxville, TN \\ 37996-1605 \\ ${ }^{5}$ Department of Geology, University of Dhaka, Dhaka 1000, Bangladesh \\ ${ }^{6}$ Department of Environmental Science, Barnard College, New York, NY 10027 \\ ${ }^{7}$ Civil Engineering and Engineering Mechanics, Columbia University, New York, NY 10027 \\ ${ }^{8}$ Lamont-Doherty Earth Observatory of Columbia University Route 9W, Palisades, NY 10964
}

\section{Abstract}

\begin{abstract}
A majority of households in Bangladesh rely on pond water for hygiene. Exposure to pond water fecal contamination could therefore still contribute to diarrheal disease despite the installation of numerous tubewells for drinking. The objectives of this study are to determine the predominant sources (human or livestock) of fecal pollution in ponds and examine the association between local population, latrine density, latrine quality and concentrations of fecal bacteria and pathogens in pond water. Forty-three ponds were analyzed for E. coli using culture-based methods and E.

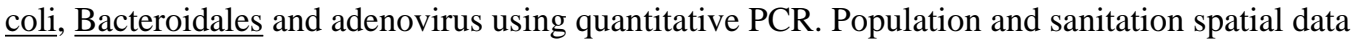
were collected and measured against pond fecal contamination. Humans were the dominant source of fecal contamination in $79 \%$ of the ponds according to Bacteroidales measurements. Ponds directly receiving latrine effluent had the highest concentrations of fecal indicator bacteria (up to $10^{6}$ Most Probable Number (MPN) of culturable E. coli per $100 \mathrm{~mL}$ ). Concentrations of fecal indicator bacteria correlated with population surveyed within a distance of $30-70 \mathrm{~m}(\mathrm{p}<0.05)$ and total latrines surveyed within 50-70 m ( $\mathrm{p}<0.05)$. Unsanitary latrines (visible effluent or open pits) within the pond drainage basin were also significantly correlated to fecal indicator concentrations $(p<0.05)$. Water in the vast majority of the surveyed ponds contained unsafe levels of fecal contamination attributable primarily to unsanitary latrines, and to lesser extent to sanitary latrines
\end{abstract}

\footnotetext{
(C) 2011 Elsevier B.V. All rights reserved.

* Present Address: Institute for Groundwater Ecology, German Research Center for Environmental Health, Ingolstaedter Landstrasse 1, 85764 Neuherberg, Germany. Telephone: +49893187 2916. Fax: +49 3187 3361. peter.knappett@helmholtz-muenchen.de Appendix A. Supplementary data: Detailed information on pond bacteria and virus concentrations are available online.

Publisher's Disclaimer: This is a PDF file of an unedited manuscript that has been accepted for publication. As a service to our customers we are providing this early version of the manuscript. The manuscript will undergo copyediting, typesetting, and review of the resulting proof before it is published in its final citable form. Please note that during the production process errors may be discovered which could affect the content, and all legal disclaimers that apply to the journal pertain.
} 
and cattle. Since the majority of fecal pollution is derived from human waste, continued use of pond water could help explain the persistence of diarrheal disease in rural South Asia.

\section{Keywords}

Diarrheal disease; fecal source tracking; Bacteroidales; adenovirus; latrine effluent; Asia

\section{Introduction}

Over the past few decades the incidence of diarrheal disease has declined throughout the developing world. Despite this decline, 1.5 million children under five die of diarrhea annually (UNICEF/WHO, 2009). The decline in diarrheal disease has generally been attributed to improved medical treatment and interventions focused on safe drinking water, as well as improved sanitation and hygiene (Esrey, 1996; Pruss et al., 2002). The inability to reduce diarrheal disease levels further suggests that transmission pathways in the developing world are complex and that environmental conditions may play a larger role than previously thought. Substantial amounts of surface water are contained in ponds scattered throughout villages in rural Bangladesh. Due to poor sanitation, ponds receive fecal contamination from numerous latrines and could be a source of pathogens overlooked by intervention programs focused exclusively on drinking water quality. Contact with pond water has previously been identified as a driver of diarrheal disease in Bangladesh when people drink, bathe in, or live near a pond (Emch et al., 2008; Ali et al., 2002). Although surface water from ponds is generally not used for drinking and cooking, it is used for bathing and brushing teeth (Aziz et al., 1990).

In recent decades, the number of ponds excavated in Bangladesh has outpaced population growth (see Supp. Material in Neumann et al., 2010). While many ponds are excavated to raise the ground to protect dwellings from flooding, they often fulfill alternate purposes, including aquaculture, bathing, irrigation, or holding latrine effluent. In the area surrounding the ponds, latrines, the primary mode of handling human feces in rural Bangladesh, are often deliberately placed, effectively creating sewage lagoons. Global studies have revealed that substantial decreases in diarrheal disease morbidity by a quarter to over a third (Fewtrell et al., 2005) and improvements in childhood nutritional indexes (Esrey, 1996) have accompanied a gradual switch from open pit latrines to more sanitary latrines consisting of concrete foundation rings to prevent leakage of human feces onto the open ground. In rural Bangladesh specifically, epidemiologic studies have reported reductions in diarrheal disease morbidity due to improved sanitation (Aziz et al., 1990; Emch, 1999; Emch et al., 2008; Hoque et al., 1996) where only half the population currently has access to sanitary latrines (WHO/UNICEF, 2008).

Although several diarrheal disease pathogens are transmitted through human feces including, Shigella and rotavirus, livestock feces can carry diarrheal pathogens including Campylobacter, Salmonella and certain types of pathogenic E. coli (Nicholson et al., 2005), all of which are routinely identified in the stools of diarrhea patients at the International Center for Diarrheal Disease Research Bangladesh (ICDDRB) hospital (Albert et al., 1999). Villagers live very close to their livestock on a daily basis and the livestock are frequently kept near ponds where latrines and tubewells are also located, resulting in opportunities for both types of fecal contamination to impact pond water quality. Therefore, understanding the relative contributions of fecal sources, as well as the impact of waste containment on surface water fecal contamination, could lead to better public health interventions. 
The goals of this study were to assess the levels and factors influencing concentrations of fecal bacteria and adenovirus in ponds within a representative village of Bangladesh. The following hypotheses were tested: 1) fecal bacteria in ponds of rural Bangladesh are primarily human in origin, rather than from domestic livestock; 2) concentrations of fecal bacteria and adenovirus are related to local population density; and 3) concentrations of fecal bacteria and adenovirus are related to the number of latrines around a pond, as well as the type of latrine. To test these hypotheses, this study integrates pond concentrations of fecal bacteria and viral pathogens with detailed spatial data from the same village. The novelty of this study is: 1) both E. coli and total Bacteroidales were compared as fecal indicators; 2) host animal specific Bacteroidales quantitative PCR assays were used to identify samples impacted by human or livestock fecal waste (Bernhard and Field, 2000; Layton et al., 2006; Lee et al., 2008); and 3) human adenovirus, representing both a human pathogen and a human fecal indicator, was analyzed (Castignolles et al. 1998; Wyn-Jones and Sellwood, 2001; Jiang, 2006).

\section{Methods}

\subsection{Site Description}

The village of Char Para is located in Araihazar upazilla, about $25 \mathrm{~km}$ east of Dhaka. Ongoing public-health and earth-science studies focused on the groundwater arsenic problem were launched in the area in 2000 (van Geen et al., 2003). Char Para, also referred to as Site K (Radloff et al., 2007), is underlain by fine to medium grained deltaic sands, which form a shallow aquifer that is tapped by tubewells that are screened from 10 to $20 \mathrm{~m}$ and are the primary drinking water source in the village. The shallow aquifer below Char Para is bounded hydrologically on three sides by a former channel of the Old Brahmaputra River which floods to the edge of the village by the late wet season (van Geen et al., 2003; Weinman et al., 2008). Many ponds in Char Para are empty at the end of the dry season in April when the groundwater table falls below the bottom of the pond. The ponds that do not dry out are often the deepest ponds, or are artificially maintained for fish farming by pumping from a deeper aquifer. Standing water can also be maintained year-round in latrine ponds that receive latrine effluent and runoff of wash water from surrounding wells. At the beginning of the monsoon in late May, some ponds may also fill and drain rapidly; fluctuations in pond water levels of up to $1 \mathrm{~m}$ were observed within 24 hours in June 2008. As a result of the initially depressed water table and the flat topography between pond basins, little mixing between surface water bodies occurs until late in the monsoon (August) when some ponds may overtop their basins.

\subsection{Field Methods and Pond Classification}

2.2.1 Village-wide GPS survey-High accuracy (sub-meter) GPS coordinates were collected for all ponds, latrines and households throughout the village during June 2009 using a Trimble GeoXH receiver and Terrasync 2.4 software (Table A1). GPS data were post-processed using Pathfinder Office 3.0 (Trimble Navigation Ltd., Sunnyvale, CA). Latrines were classified as sanitary if the concrete platform and rings were intact with no visible sign of effluent discharging onto the ground. A latrine was classified as unsanitary if the ring was absent or cracked, or if visible effluent discharged directly into a pond via a PVC pipe. A population survey was conducted to determine pond ownership and the number of persons living in each household (cattle were not counted during the village-wide survey). Population and latrine totals within a given radius of each pond were determined using the buffer and intersect tools in ArcGIS software. The population and number of latrines (sanitary and unsanitary) surrounding ponds within a radius of 10 and $50 \mathrm{~m}$ was calculated at 5-m intervals and within a radius of 50 to $100 \mathrm{~m}$ at $10-\mathrm{m}$ intervals. This method is referred to hereon as the spatial buffer method. 
2.2.2 Pond drainage basin survey-An alternative survey was carried out in June 2008 to identify latrines within a radius of $\sim 20 \mathrm{~m}$ of a pond located within drainage basin that sloped downward toward the water edge. The rationale for this hydrological approach is that latrines within the basin could have a greater influence on microbial pond water quality than latrines at similar distances outside the drainage basin. Information collected for each pond drainage basin includes water depth, long and short axes of the pond water surface (measured in meters), designated purpose as identified by the owner, number and type of latrines (unsanitary or sanitary) and the number of cattle residing within the drainage basin (Table A1). Ponds receiving direct latrine effluent were classified as latrine ponds. Unless local households identified a specific use such as bathing or aquaculture, ponds not receiving direct latrine effluent were categorized as having no specific use. Specific conductivity, $\mathrm{pH}$, dissolved oxygen and temperature were measured at each pond at the time of microbial sampling using a calibrated handheld multiprobe (556 Multiprobe System, YSI Inc., Yellow Springs, OH).

\subsection{Microbiological Assays}

Water from 43 ponds was collected in sterile bottles in mid-June 2008, during the early monsoon when surface runoff was common but the ponds were not yet full. One hundred $\mathrm{mL}$ pond water samples were collected in sterile containers to measure culturable E. coli using the MPN based Colilert ${ }^{\mathrm{TM}}$ test kit (IDEXX Laboratories, Inc., Westbrook, ME). Triplicate samples were taken from the first 30 ponds, and after the Coefficient of Variation (C.V.) between replicates was found to be low (24\%), remaining ponds were sampled in duplicate (C.V. 31\%). Based on the assumption that replicates contained the same true concentration of cultured E. coli cells, triplicate and duplicate samples were pooled to produce a single MPN with 95\% confidence intervals (Hurley and Roscoe, 1983; Knappett et al., 2010). Pond water samples were diluted 1:100 or 1:1000 with commercial bottled drinking water before being assayed to avoid exceeding the quantifiable maximum of 2419 bacteria/100 $\mathrm{mL}$ of the assay. The minimum detection limit of a single Colilert ${ }^{\mathrm{TM}}$ analysis is $1 \mathrm{MPN} / 100 \mathrm{~mL}$, however since each sample was diluted at least 100 times, the detection limit became $100 \mathrm{MPN} / 100 \mathrm{~mL}$. All but 1 pond had culturable E. coli concentrations above the $100 \mathrm{MPN} / 100 \mathrm{~mL}$ detection limit. Laboratory blanks using bottled water were included every thirty $100 \mathrm{~mL}$ samples to control for contamination during processing.

For the molecular measurements as much pond water as could be filtered before clogging, was filtered through a $0.22 \mu \mathrm{m}$ nitrocellulose filter $(150 \mathrm{~mL}$ Vacuum Driven Disposable Filtration System, Stericup, HV Durapore Membrane, Millipore Corp., Bedford, MA). The volumes filtered ranged from 40 to $295 \mathrm{~mL}$. Filters were removed from the plastic housing, placed in sterile petri plates, kept on ice less than 8 hours and then frozen for $\sim 1$ week at $-10^{\circ} \mathrm{C}$ and transported on dry ice to the University of Tennessee where they were stored at $-80^{\circ} \mathrm{C}$. DNA was extracted and purified from the filters using the FastDNA ${ }^{\circledR}$ SPIN for Soil Kit (MP Biomedicals, LLC, Solon, OH) following the manufacturer's protocols. The original extracted DNA was quantified using a NanoDrop Spectophotometer (ThermoScientific, Wilmington, DE) and diluted up to 40 fold prior to qPCR to obtain a concentration between 5 and $10 \mathrm{ng} / \mu \mathrm{l}$ in order to minimize potential PCR inhibition.

Quantitative PCR (qPCR) was performed using assays designed for $\underline{\text { E. coli and total }}$ Bacteroidales, three host-associated Bacteroidales assays (two for human and one for bovine), and the human pathogen adenovirus (Table 1). The gene targets for the E. coli and Bacteroidales assays were the 23S rRNA gene (Smith et al., 1999; Layton et al., 2003) and the 16S rRNA gene, respectively, with the human and bovine host-associated assays targeting different subgroups within the Bacteroidales order (Bernhard and Field, 2000; Layton et al., 2006; Seurinck et al., 2005). Genome equivalents of E. coli (using the $23 \mathrm{~S}$ 
rRNA molecular target) detected in a water sample are hereon referred to as $\underline{\mathrm{mE} \text {. coli }}$ (molecular) to distinguish them from cultured E. coli. The adenovirus gene target was the hexon gene from serotypes 40 and 41 (Rajal et al., 2007) which encodes the major capsid protein for the adenovirus (Ebner et al., 2005).

All qPCR reactions consisted of $12.5 \mu \mathrm{l}$ PCR mix (Stratagene, LaJolla, CA), $0.75 \mu \mathrm{l}$ of a 20 $\mu \mathrm{M}$ stock of each of the forward primer and reverse primers, and $0.5 \mu \mathrm{l}$ of a $10 \mu \mathrm{M}$ stock of the probe (Table 1), $8 \mu \mathrm{l}$ of sterile water and $2.5 \mu \mathrm{l}$ of sample or standard for a final reaction volume of $25 \mu \mathrm{l}$. PCR amplification and fluorescent probe detection were performed using the Chromo4 Real-Time PCR Detection system (BioRad, Hercules, CA) and the following amplification protocol: $50^{\circ} \mathrm{C}$ for 2 minutes, $95^{\circ} \mathrm{C}$ for ten minutes, and 45 cycles of alternating $95^{\circ} \mathrm{C}$ for 30 seconds and the annealing temperatures as indicated in Table 1 for 45 seconds. Calibration of the qPCR assays using a standard curve involved cloning the target gene into a plasmid for all assays except for the $\mathrm{mE}$. coli assays which used $\underline{\mathrm{E} \text {. coli }}$ O157 genomic DNA (Strain EDL 933, ATCC 43895D-5). For plasmid standards, serial 10x dilutions were performed in triplicate from a starting concentration of $1 \times 10^{7}$ plasmid copies to 10 copies per $\mu \mathrm{l}$ and $2.5 \mu \mathrm{l}$ of each plasmid dilution were placed in triplicate wells.

Similarly the E. coli O157 genomic DNA was diluted serially from a starting concentration of $1 \times 10^{6}$ to 10 genomic equivalents per $\mathrm{mL}$ and $2.5 \mu \mathrm{l}$ of each plasmid dilution was placed in triplicate wells. All qPCR assays were performed in triplicate for each sample with a fourth well spiked with $2.5 \times 10^{5}$ copies of the standard in order to monitor PCR inhibition using Eq. (A.1) to calculate recovery efficiency as described previously (Bell et al., 2009; Layton et al., 2006). Recovery efficiency is also referred to as the inhibition factor by others (Yamahara et al. 2009). One sample had PCR inhibition, so it was removed from all subsequent data analysis. In rare cases where the standard deviation exceeded the mean gene concentration in the 3 wells (C.V. > 100\%), the assay for that marker was re-run. Final concentrations of target copies in original water samples were calculated using Eq. (A.2).

The method detection limit (MDL in copies $/ 100 \mathrm{~mL}$ ) was variable due to dilution of extracted DNA to limit inhibition that may accompany water samples with high biomass. The MDL for each sample was determined when the copies of target DNA were less than 1 copy per ng of total DNA in the qPCR reaction well. Each extracted DNA sample was diluted down to 5 to $10 \mathrm{ng} / \mu \mathrm{l}$ and therefore the limit for each sample $(2.5 \mu \mathrm{l})$ ranged from 12.5 to 25 copies per qPCR reaction, which was within the range of quantification on the standard curve. Since the initial concentration of total DNA extracted from the samples varied from 8 to $413 \mathrm{ng} / \mu \mathrm{l}$ and the volume of pond water filtered ranged from 40 to $295 \mathrm{~mL}$, the MDL also varied between samples (Eq. (A.2)) with a geometric mean of $8.4 \times 10^{3}$ and a range of $1.4 \times 10^{3}$ to $2.1 \times 10^{5}$ copies $/ 100 \mathrm{~mL}$. For each sample, this MDL was the same for all molecular targets.

\subsection{Statistical Analysis}

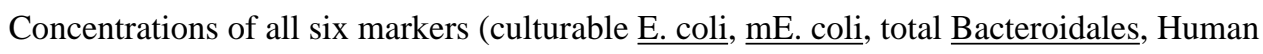
and Bovine Bacteroidales and adenovirus) were compared using a non-parametric correlation matrix which reports the Spearman Rank Order Correlation Coefficient $\underline{\underline{r}}_{\underline{s}}$ and significance level $(\mathrm{p}<0.05)$. The non-parametric Kruskal-Wallis test was performed using NCSS software (version 07.1.14, NCSS, LLC, Kaysville, UT) to determine concentration differences between pond groups based on type $(\mathrm{p}<0.05)$. Associations between population and spatial-buffer latrine counts (sanitary, unsanitary, total) within 10 to $100 \mathrm{~m}$ of a pond and concentrations of pond water markers were also tested using the Spearman Rank Order Coefficient. For samples Below Detection Limit (BDL) the geometric mean qPCR detection limit $\left(8.4 \times 10^{3}\right.$ copies $\left./ 100 \mathrm{~mL}\right)$ was substituted. Half (11) of the total BDL's (23) were for Bovine Bacteroidales (26\% substitution rate) indicating that correlation statistics reported for Bovine Bacteroidales here should be considered as semi-quantitative estimates (Table 
A2). For the other markers this method of data censoring likely had little impact on the reported statistics with only 5\% (12/215) of marker analyses BDL (Helsel, 2006; Antweiler and Taylor, 2008).

\section{Results}

\subsection{Physical and Chemical Attributes of Ponds}

All 43 ponds found within the $0.3 \mathrm{~km}^{2}$ area of the village were sampled in June 2008. Of the ponds sampled, 11 were designated by the owner as fish or bathing ponds and 16 had no designated purpose (Fig. 1). The remaining 16 ponds were classified as latrine ponds because they received direct effluent from at least one latrine. Pond surface area ranged from 20 to $1,200 \mathrm{~m}^{2}$. The largest ponds were commercial fishing and community bathing ponds, located in the northeast section of the village and contain water year round by pumping from wells (Fig. 1).

Specific conductivity may be a proxy for fecal contamination in these ponds due to high salt concentrations in animal feces (Manahan, 2005). The specific conductivity of water in latrine ponds (median $0.41 \mathrm{mS} / \mathrm{cm}$ ) was found to be higher than in fish/bathing ponds $(0.17$ $\mathrm{mS} / \mathrm{cm}$ ) (Fig. 2a). Similarly, dissolved oxygen concentrations are depleted in waters receiving human or animal excrement, and in the present study latrine ponds (median 0.24 $\mathrm{ppm})$ were lower compared with fish/bathing ponds $(0.68 \mathrm{ppm})(\mathrm{p}<0.05)$, while the fish/ bathing ponds had the largest range of dissolved oxygen $(0.23-1.51 \mathrm{ppm})$ (Fig. $2 \mathrm{~b})$. Temperature, a factor known to influence the persistence of fecal bacteria and their molecular markers in surface water (Bell et al., 2009), ranged from 27 to $34^{\circ} \mathrm{C}$ (Fig. 2c), with higher temperature ponds located on the edges of the village or in fields, where there is little to no shade. The smaller and cooler ponds, often latrine ponds, were located in the interior of the village and typically surrounded by trees. Median specific conductivity (Fig. 2a), dissolved oxygen (Fig. 2b) and temperature (Fig. 2c), for ponds without a defined use were intermediate between median values for fish/bathing and latrine ponds.

\subsection{Concentrations of indicator bacteria and genetic markers}

In the 43 ponds sampled, cultured E. coli were detected in 42 , $\underline{\mathrm{mE} \text {. coli in } 39 \text {, Bacteroidales }}$ in 43 and adenovirus in 41. Human and Bovine Bacteroidales were detected in 36 and 24 ponds respectively (Table A2). In the ponds with detectable Human and Bovine Bacteroidales, copy numbers ranged from $1.3 \times 10^{4}$ to $6.8 \times 10^{7}$ and $3.3 \times 10^{4}$ to $7.0 \times 10^{6}$ copies $/ 100 \mathrm{~mL}$, respectively. Adenovirus copy numbers ranged from $1.3 \times 10^{4}$ to $8.8 \times 10^{6}$ copies/100 mL.

Most Probable Numbers of cultured E. coli in the 43 ponds ranged from non-detect $(<100$ MPN/100 mL) to $9.7 \times 10^{5}$ MPN/100 mL (Fig. 2d). Ponds with the highest Most Probable Numbers of culturable E. coli tended to be located in the central part of the village (Fig. 1). $\mathrm{mE}$. coli genome numbers ranged from non-detect $\left(<8.4 \times 10^{3}\right.$ copies $\left./ 100 \mathrm{~mL}\right)$ to $3.2 \times 10^{7}$ copies $/ 100 \mathrm{~mL}$ (Fig. 2e). The $\log _{10}$-transformed concentrations of culturable E. coli cells and $\mathrm{mE}$. coli genomes were fit to an exponential curve using linear regression $\left(\mathrm{R}^{2}=0.43\right)$ (Fig. 3a). The median proportion of E. coli culturable was $2.4 \%\left(25^{\text {th }}, 75^{\text {th }}\right.$ percentile $=0.7$, $6.1 \%$ respectively). Although pond temperature varied from $27{ }^{\circ} \mathrm{C}$ within the village to 34 ${ }^{\circ} \mathrm{C}$ outside, the ratio of cultured to molecular E. coli was uncorrelated with temperature. The correlation between $\mathrm{mE}$. coli genomes and cultured $\mathrm{E}$. coli, and the higher abundance of $\mathrm{mE}$.

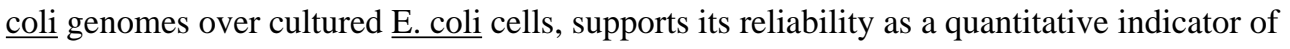
fecal pollution.

As a distinct species of bacteria abundant in the intestines of warm blooded organisms $\underline{\text { Bacteroidales is a fecal indicator independent from } \underline{E} \text {. coli. Pond water total Bacteroidales }}$ 



3b, Table 2). In 34 out of 38 samples where at least one host-specific marker was detected, the concentration of human Bacteroidales exceeded that of bovine Bacteroidales (Fig. 4). Although total Bacteroidales were detected in all ponds, neither human nor bovine

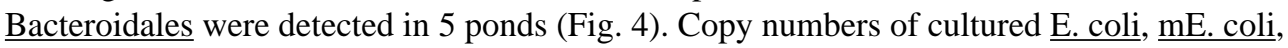
and total Bacteroidales in pond water were all significantly correlated (Table 2) reinforcing total Bacteroidales as a quantitative indicator of the degree of fecal contamination in the ponds. Adenovirus was present in the majority of ponds but its copy numbers were uncorrelated to fecal indicator bacteria concentrations (Table 2) and pond type (Fig. A3).

Fish/bathing ponds were significantly less contaminated than latrine ponds according to measurements on the three quantitative fecal indicator bacteria (Fig. 2d, e, f) $(p<0.05)$. The median concentrations of fecal indicators in ponds without a defined use were intermediate of corresponding median concentrations in latrine and fish/bathing ponds. The median cultured E. coli MPN's (with associated $25^{\text {th }}$ and $75^{\text {th }}$ percentiles) for latrine, no defined use and fish/bathing ponds were $2.1 \times 10^{4}\left(7.9 \times 10^{3}, 2.2 \times 10^{5}\right), 4.3 \times 10^{3}\left(2.1 \times 10^{3}, 4.9 \times 10^{4}\right)$ and $2.7 \times 10^{3},\left(5.1 \times 10^{2}, 4.4 \times 10^{3}\right) \mathrm{MPN} / 100 \mathrm{~mL}$ respectively.

\subsection{Population Density and Pond Contamination}

Approximately 1500 people live within Char Para. The Spearman rank correlation coefficient between the spatial-buffer population count and the concentration of the various microbial markers was calculated for distances from a pond ranging from 10-100 m (Fig. A2a). The association between population and fecal bacteria concentrations was maximized at a $45 \mathrm{~m}$ spatial-buffer radius with all fecal indicator bacteria showing significant correlations to population ( $\mathrm{p}<0.05$ ). Population within $45 \mathrm{~m}$ of each pond ranged from zero to 126 people (Table A4).

High Spearman correlations are obtained for population within $45 \mathrm{~m}$ of each pond and all

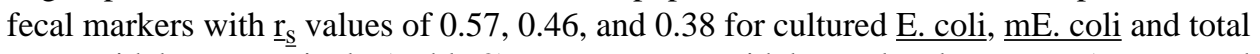
Bacteroidales respectively (Table 2). Human Bacteroidales molecular targets (HuBac and HF 183), at least one of which were detected in 36 out of 43 samples, correlated significantly to the population within $45 \mathrm{~m}$ of the pond $\left(\underline{r}_{\underline{S}}=0.34\right)$ as did Bovine Bacteroidales $\left(\underline{r}_{\underline{s}}=0.36\right)$. In contrast, adenovirus was uncorrelated to population at any spatial-buffer distance.

\subsection{Latrine Density and Pond Contamination}

A total of 178 latrines could be located during the village-wide GPS survey (Fig. 1), 79 $(42 \%)$ of which were sanitary latrines, similar to the proportion observed elsewhere in Bangladesh (WHO/UNICEF, 2008). Of the 99 unsanitary latrines, 22 were open pit latrines. With respect to latrines and ponds the survey was exhaustive within the boundaries of the village, however open pit latrines were difficult to find, and therefore some may have been missed. Most Probable Numbers of cultured E. coli were significantly correlated with the total number of latrines located within 20 to $80 \mathrm{~m}$ of a pond (p<0.05) (Fig. A2b). The total number of latrines ranged from 0 to 8 within a $20 \mathrm{~m}$ spatial-buffer and 0 to 34 within $80 \mathrm{~m}$. The correlation between number of unsanitary latrines and cultured E. coli concentration was significant across the spatial-buffer range of 15 to $80 \mathrm{~m}$ (Fig. A2c). Correlations between unsanitary latrines and molecular targets per $100 \mathrm{~mL}$ of $\mathrm{mE}$. coli and total Bacteroidales, however, were only marginally significant $(\mathrm{p} \sim 0.05)$ at distances ranging from 80 to $100 \mathrm{~m}$. Sanitary latrine counts were correlated with Most Probable Numbers of $\underline{E}$. coli within 40 to $70 \mathrm{~m}$ from a pond (Fig. A2d). Adenovirus copy numbers were not correlated with any type of latrine (total, unsanitary or sanitary) at any distance (Fig. A2b, c, d). 
The optimal distance for correlations between latrine counts and fecal bacteria was $60 \mathrm{~m}$, since this was the only radius that resulted in significant correlations with all three total fecal indicator bacteria, cultured E. coli, $\mathrm{mE}$. coli and total Bacteroidales (Fig. A2b). The correlation between $\underline{E}$. coli and the total number of latrines $\left(\underline{r}_{\underline{s}}=0.40\right)$ within $60 \mathrm{~m}$ of a pond was stronger than either unsanitary $(0.33)$ or sanitary latrines $(0.31)$ considered separately (Table 2). $\mathrm{mE}$. coli and total Bacteroidales correlated to total latrine counts within $60 \mathrm{~m}$ of the pond with $\underline{\mathrm{r}}_{\mathrm{s}}$ equal to 0.37 and 0.36 respectively. Considering the number of unsanitary latrines only within the pond drainage basin resulted in correlations with fecal indicators $\underline{E}$.


stronger than those using spatial-based latrine counts (Table 2), and contrast with the lack of correlation between fecal indicator bacteria and sanitary latrines counted within each pond drainage basin.

\section{Discussion}

\subsection{Population and Sanitation Influences on Fecal Bacteria Concentrations}

There is an urgent need to better understand the role of the environment in the transmission of diarrheal disease in Bangladesh where an estimated $11 \%$ of all deaths are attributable to diarrheal disease (Streatfield et al., 2001). Exposure to pond water is a risk factor for diarrheal disease in rural Bangladesh (Emch et al., 2008; Ali et al., 2002), so understanding the sources of fecal contamination and environmental factors affecting the degree of pond fecal contamination is import in the development of a suitable strategy to limit human exposure to fecal waste. This study tested three hypotheses: 1) fecal bacteria in ponds originate primarily from humans rather than cattle; 2 ) concentrations of fecal bacteria and adenovirus are related to local population density; and 3) concentrations of fecal bacteria and adenovirus are related to the number of latrines around a pond, as well as the type of latrine. Both the frequency of detection and concentrations of human host-specific Bacteroidales exceeded the bovine host-specific Bacteroidales indicating that pond water fecal pollution in Char Para is overwhelmingly of human origin. The widespread presence of human adenovirus (41 out of 43 ponds) also supports this hypothesis. Although cattle are abundant in villages, cattle manure serves as fuel for cooking and is therefore collected and traded in rural Bangladesh, which may explain the relatively low, but widespread abundance of bovine-specific markers. Fecal bacteria marker concentrations were positively correlated with population and latrine density within $45 \mathrm{~m}$ of the pond strengthening the quantitative link between human fecal sources and pond contamination. In contrast, copies per $100 \mathrm{~mL}$ of adenovirus were not correlated to population density, total latrines, or any other variables, suggesting that factors influencing adenovirus copy numbers are more complex than those influencing fecal bacteria concentrations.

Latrines were categorized as sanitary or unsanitary based on previously identified associations between diarrheal disease incidence and the number of unsanitary latrines surrounding a dwelling (Emch et al., 2008). In this study, the number of unsanitary latrines within each pond drainage basin was correlated to fecal bacteria concentrations ( $p<0.05)$, whereas the number of sanitary latrines was not, demonstrating the negative impact of unsanitary latrines on neighboring surface water. This unsanitary latrine category included 22 (out of 99) make-shift above-ground latrines consisting of two bricks on the ground. The difficulty of finding these relatively secluded "latrines" suggests many more than were found may be present and causing pollution, highlighting the importance of properly functioning latrines to minimize fecal contamination of bathing ponds in densely populated villages similar to those in Bangladesh.

The number of unsanitary latrines within a pond drainage basin was more predictive of fecal indicator bacteria concentrations than spatial-buffer counts of any latrine type (total, 
sanitary, unsanitary) within a $60 \mathrm{~m}$ radius of each pond (Table 2). The fact that unsanitary latrine counts within pond drainage basins were more predictive is likely the result of topography surrounding each pond that determines the direction of latrine effluent and surface runoff flow. Latrines are often placed near ponds for aesthetic reasons and these latrines will have the greatest influence on pond water quality.

\subsection{Correlations Between Fecal Bacteria and Adenovirus Markers}

The cultured fecal indicator bacteria E. coli, and molecular markers for $\mathrm{mE}$. coli and total Bacteroidales correlated strongly with each other indicating that any three of these assays may be used to evaluate levels of pond water fecal contamination. Total Bacteroidales molecular targets were consistently detected in higher numbers than E. coli genomes and thus may be advantageous in some settings for detecting lower concentrations of fecal contamination. Bacteroidales are obligate anaerobes and their persistence is sensitive to both oxygen and temperature (Bell et al., 2009). Walters and Field (2009) measured more rapid decreases in target copy numbers of Human Bacteroidales than cultured E. coli, with $\mathrm{T}_{90}$ 's, the time required for a concentration decrease of $90 \%$ based on measured decay rates, of 1.9 and 7.9 days respectively (sewage-seeded, fresh water, dark microcosms). In contrast to Bacteroidales, E. coli may be retained longer in the environment but may also re-grow with a recent study suggesting that some strains of $\underline{E}$. coli may be endogenous to soil bacteria (Nautiyal et al., 2010). In the present study, the strong correlation between E. coli and Bacteroidales, however, indicates that these differential die-off and re-growth processes did not diminish the efficacy of Bacteroidales as a quantitative fecal indicator in surface waters. The ratio of culturable E. coli to E. coli genomes was not influenced by pond type and temperature, indicating that neither nutrient availability nor temperature affected the proportion of culturable genomes in the pond samples.

Although widely detected, adenovirus copy numbers were not correlated with any of the fecal indicator bacterial markers. Similarly, Bofill-Mas et al. (2010) found widespread occurrence of adenovirus in European fresh and marine waters (80 out of 132 samples positive), whereas only 3 of 15 laboratories found significant correlations between cultured E. coli cell numbers and adenovirus copy numbers $(\mathrm{p}<0.05)$. These findings may be partially explained by the high stability of adenovirus in wastewaters with a measured $\mathrm{T}_{90}$ of 61 days (Bofill-Mas et al., 2006). Walters et al. (2009) found that in contrast with Human-specific Bacteroidales, enterovirus copy numbers were relatively stable and not susceptible to the effects of solar radiation. These differences in inactivation rates and processes between viruses and fecal indicator bacteria may explain the poor correlations typically observed in surface waters (Lee et al., 2004; Wilkes et al., 2009).

Significant positive correlations $(\mathrm{p}<0.05)$ were observed between all fecal indicator bacteria and specific conductivity (Table 2). Conductivity is likely to rise with increased anthropogenic use of the pond catchment area, including salt inputs from human waste (Manahan, 2005) and the use of ash for washing (Hoque et al., 1995; Sengupta et al., 2008) coupled with pond water evaporation, and may therefore be a proxy for human usage and pond water contamination.

\subsection{Implications for the Spread of Diarrheal Disease}

Most Probable Numbers of E. coli in the surveyed ponds exceeded the U.S. EPA recreational water quality limit (126 MPN/100 mL) up to 10,000 times (US EPA, 1986) and were in fact similar in concentration to fecal coliforms typically detected in untreated wastewater (Sinton et al., 1999; Passerat et al., 2011). A global epidemiological metaanalysis determined that for every $1 \log _{10}$ increase in E. coli the odds of acquiring diarrheal disease from recreational contact approximately doubles (Wade et al., 2003). Bathing and 
fishing ponds contained 1-2 $\log _{10}$ less culturable E. coli than latrine ponds suggesting that diarrheal disease risk from exposure to latrine ponds is 2 to 4 times higher than for protected ponds. However, even fishing and bathing ponds had high levels of all fecal indicators, $\underline{E}$. $\underline{\text { coli, }}, \underline{\mathrm{mE}}$. coli, total Bacteroidales and human Bacteroidales with median concentrations of $10^{3}$ (MPN), $10^{5}, 10^{6}$ and $10^{5}$ (copies) per $100 \mathrm{~mL}$ respectively. These high levels of fecal pollution as well as the widespread detection of the human gastrointestinal pathogen adenovirus, and close proximity to human dwellings implicate these ponds as likely sources of persistent diarrheal disease. Human exposure to fecal contamination will therefore be limited by the continued upgrading and maintenance of latrines and the placement of these latrines outside of the immediate pond drainage basin.

\section{Supplementary Material}

Refer to Web version on PubMed Central for supplementary material.

\section{Acknowledgments}

This study was supported by grant 5 R01 TW008066 from the NIH/FIC Ecology of Infectious Disease program. Funding was also provided by the Center for Environmental Biotechnology and the Institute for a Secure and Sustainable Environment at the University of Tennessee. Tillmann Lueders is thanked for his review of the manuscript as well as three anonymous reviewers who greatly improved the quality of the final product.

\section{References}

Albert MJ, Faruque ASG, Faruque SM, Sack RB, Mahalanabis D. Case-control study of enteropathogens associated with childhood diarrhea in Dhaka, Bangladesh. J Clin Microbiol. 1999; 37:3458-64. [PubMed: 10523534]

Ali M, Emch M, Donnay JP, Yunus M, Sack RB. The spatial epidemiology of cholera in an endemic area of Bangladesh. Soc Sci Med. 2002; 55:1015-24. [PubMed: 12220086]

Antweiler RC, Taylor HE. Evaluation of Statistical Treatments of Left-Censored Environmental Data using Coincident Uncensored Data Sets: I. Summary Statistics. Environ Sci Technol. 2008; 42:3732-3738. [PubMed: 18546715]

Aziz, KMA.; Hoque, BA.; Huttly, SRA.; Minnatullah, KM.; Hasan, Z.; Patwary, MK.; Rahaman, MM.; Cairncross, S. United Nations Development Programme - World Bank Water and Sanitation Program. The World Bank; Washington, DC: 1990. Water Supply, Sanitation and Hygiene Education: Report of a Health Impact Study in Mirzapur, Bangladesh.

Bernhard AE, Field KG. Identification of nonpoint sources of fecal pollution in coastal waters by using host-specific 16S ribosomal DNA genetic markers from fecal anaerobes. Appl Environ Microbiol. 2000; 66:1587-94. [PubMed: 10742246]

Bell A, Layton AC, McKay L, Williams D, Gentry R, Sayler GS. Factors influencing the persistence of fecal Bacteroides in stream water. J Environ Qual. 2009; 38:1224-32. [PubMed: 19398520]

Castignolles N, Petit F, Mendel I, Simon L, Cattolico L, Buffet-Janvresse C. Detection of adenovirus in the waters of the Seine River estuary by nested-PCR. Mol Cell Probe. 1998; 12:175-180.

Ebner K, Pinsker W, Lion T. Comparative Sequence Analysis of the hexon Gene in the Entire Spectrum of Human adenovirus Serotypes: Phylogenetic, Taxonomic, and Clinical Implications. J Virol. 2005; 79:12635-42. [PubMed: 16188965]

Emch M. Diarrheal disease risk in Matlab, Bangladesh. Soc Sci Med. 1999; 49:519-30. [PubMed: 10414811]

Emch M, Ali M, Yunus M. Risk areas and neighborhood-level risk factors for Shigella dysenteriae 1 and Shigella fexneri. Health Place. 2008; 14:96-115. [PubMed: 17602851]

Esrey SA. Water, Waste, and Well-Being: A Multicountry Study. Am J Epidemiol. 1996; 143:608-23. [PubMed: 8610678] 
Fewtrell L, Kaufmann RB, Kay D, Enanoria W, Haller L, Colford JM Jr. Water, sanitation, and hygiene interventions to reduce diarrhea in less developed countries: a systematic review and meta-analysis. Lancet Infect Dis. 2005; 5:42-52. [PubMed: 15620560]

Helsel DR. Fabricating data: How substituting values for nondetects can ruin results, and what can be done about it. Chemosphere. 2006; 65:2434-2439. [PubMed: 16737727]

Hoque BA, Juncker T, Sack RB, Ali M, Aziz KM. Sustainability of a water, sanitation and hygiene education project in rural Bangladesh: a 5-year follow-up. B World Health Organ. 1996; 74:431437.

Hoque BA, Mahalanabis D, Alam MJ, Islam MS. Post-Defecation Handwashing in Bangladesh Practice and Efficiency Perspectives. Public Health. 1995; 109:15-24. [PubMed: 7871142]

Hurley MA, Roscoe ME. Automated statistical-analysis of microbial enumeration by dilution series. J App Bacteriol. 1983; 55:159-64.

Jiang SC. Human adenoviruses in water: Occurrence and health implications: A critical review. Environ Sci Technol. 2006; 40:7132-40. [PubMed: 17180959]

Knappett PSK, Layton A, McKay LD, Williams D, Mailloux BJ, Huq MR, Alam MJ, Ahmed KM, Akita Y, Serre ML, Sayler GS, van Geen A. Efficacy of Hollow-Fiber Ultrafiltration for Microbial Sampling in Groundwater. Groundwater. 2010; 49:53-65.

Layton A, McKay LD, Williams D, Garrett V, Gentry R, Sayler G. Development of Bacteroides 16S rRNA gene TaqMan-based real-time PCR assays for estimation of total, human, and bovine fecal pollution in water. Appl Environ Microbiol. 2006; 72:4214-24. [PubMed: 16751534]

Layton, A.; Williams, D.; Sayler, GS.; McKay, LD. Proceedings of the 13th Annual Tennessee Water Resources Symposium, Tennessee Section of the AWRA; 2003.

Lee C, Lee SH, Han E, Kim SJ. Use of cell culture-PCR assay based on combination of A549 and BGMK cell lines and molecular identification as a tool to monitor infectious andenoviruses and enteroviruses in river water. Appl Environ Microbiol. 2004; 70:6695-6705. [PubMed: 15528536]

Lee YJ, Molina M, Domingo JWS, Willis JD, Cyterski M, Endale DM, Shanks OC. Temporal Assessment of the Impact of Exposure to Cow Feces in Two Watersheds by Multiple HostSpecific PCR Assays. Appl Environ Microbiol. 2008; 74:6839-47. [PubMed: 18806002]

Manahan, SE. Environmental chemistry. 8th. Boca Raton, FL: CRC Press LLC; 2005.

Nautiyal CS, Rehman A, Chauhan PS. Environmental Escherichia coli occur as natural plant growthpromoting soil bacterium. Arch Microbiol. 2010; 192:185-93. [PubMed: 20084366]

Neumann RB, Ashfaque KN, Badruzzaman ABM, Ali MA, Shoemaker JK, Harvey CF. Anthropogenic influences on groundwater arsenic concentrations in Bangladesh. Nat Geosci. 2010; 3:46-52.

Nicholson FA, Groves SJ, Chambers B. Pathogen survival during livestock manure storage and following land application. Bioresour Technol. 2005; 96:135-43. [PubMed: 15381209]

Passerat J, Ouattara NK, Mouchel J, Rocher V, Servais P. Impact of an intense combined sewer overflow event on the microbiological quality of the Seine River. Water Res. 2011; 45:893-903. [PubMed: 20934197]

Pruss A, Kay D, Fewtrell L, Bartram J. Estimating the Burden of Disease from Water, Sanitation, and Hygiene at a Global Level. Environ Health Persp. 2002; 110:537-42.

Radloff KA, Cheng A, Rahman MW, Ahmed KM, Mailloux BJ, Juhl AR, Schlosser P, van Geen A. Mobilization of arsenic during one-year incubations of grey aquifer sands from Araihazar, Bangladesh. Environ Sci Technol. 2007; 41:3639-45. [PubMed: 17547190]

Rajal VB, McSwain BS, Thompson DE, Leutenegger CM, Wuertz S. Molecular quantitative analysis of human viruses in California storm water. Water Res. 2007; 41:4287-98. [PubMed: 17628629]

Sengupta S, McArthur JM, Sakar A, Leng MJ, Ravenscroft P, Howarth RJ, Banerjee DM. Do ponds cause arsenic-pollution of groundwater in the Bengal Basin? An answer from West Bengal. Environ Sci Technol. 2008; 42:5156-64. [PubMed: 18754363]

Seurinck S, Defoirdt T, Verstraete W, Siciliano S. Detection and quantification of the human specific HF183 Bacteroides 16S rRNA genetic marker with real-time PCR for assessment of human fecal pollution in freshwater. Environ Micro. 2005; 7:249-59.

Sinton LW, Finlay RK, Lynch PA. Sunlight inactivation of fecal bacteriophages and bacteria in sewage-polluted seawater. Appl Environ Microbiol. 1999; 65:3605-13. [PubMed: 10427056] 
Smith GJ, Helf M, Nesbet C, Betita HA, Meek J, Ferre F. Fast and accurate method for quantitating E. coli host-cell DNA contamination in plasmid DNA preparations. Biotechniques. 1999; 26:518525. [PubMed: 10090994]

Streatfield, K.; Persson, LA.; Chowdhury, HR.; Saha, KK. Disease Patterns in Bangladesh: Present and Future Needs. Dhaka, Bangladesh: International Centre for Diarrhoeal Disease Research, Bangladesh; 2001.

United Nations Children's Fund and World Health Organization. Diarrhoea: Why children are still dying and what can be done. 2009. http://whqlibdoc.who.int/publications/2009/9789241598415_eng.pdf

United States Environmental Protection Agency. Bacteriological Water Quality Criteria for Marine and Fresh Recreational Waters, EPA-440/5-84-002. Cincinnati, OH: U.S. Environmental Protection Agency, Office of Water Regulations and Standards; 1986.

van Geen A, Zheng Y, Versteeg R, Stute M, Horneman A, Dhar R, Steckler M, Gelman A, Small C, Ahsan H, Graziano JH, Hussain I, Ahmed KM. Spatial variability of arsenic in 6000 tube wells in a $25 \mathrm{~km}^{2}$ area of Bangladesh. Water Resour Res. 2003; 39:1140. Online 31 May 2003. 10.1029/2002WR001617

Wade TJ, Pai N, Eisenberg JNS, Colford JM. Do US Environmental Protection Agency water quality guidelines for recreational waters prevent gastrointestinal illness? A systematic review and metaanalysis. Environ Health Persp. 2003; 111:1102-9.

Walters SP, Field KG. Survival and persistence of human and ruminant-specific Bacteroidales in freshwater microcosms. Environ Microbiol. 2009; 11:1410-21. [PubMed: 19397677]

Walters SP, Yamahara KM, Boehm AB. Persistence of nucleic acid markers of health-relevant organisms in seawater microcosms: Implications for their use in assessing risk in recreational waters. Water Res. 2009; 43:4929-39. [PubMed: 19616273]

Weinman B, Goodbred SL Jr, Zheng Y, Aziz Z, Steckler M, van Geen A, Singhvi AK, Nagar YC. Contributions of floodplain stratigraphy and evolution to the spatial patterns of groundwater arsenic in Araihazar, Bangladesh. Bull Geo Soc Am. 2008; 120:1567-80.

Wilkes G, Edge T, Gannon V, Jokinen C, Lyautey E, Medeiros D, Neumann N, Ruecker N, Topp E, Lapen DR. Seasonal Relationships Among Indicator Bacteria, Pathogenic Bacteria, Cryptosporidium Oocysts, Giardia Cysts, and Hydrological Inidices for Surface Waters Within an Agricultural Landscape. Water Res. 2009; 43:2209-2223. [PubMed: 19339033]

World Health Organization and United Nations Children's Fund Joint Monitoring Programme. People's Republic of Bangladesh: improved sanitation coverage estimates (1980-2006). Geneva Switzerland: World Health Organization and United Nations Children's Fund; 2008. http://documents.wssinfo.org/resources/documents.htmL

Wyn-Jones AP, Sellwood J. Enteric viruses in the aquatic environment. J App Microbiol. 2001; 91:945-962.

Yamahara KM, Walters SP, Boehm AB. Growth of Enterococci in Unaltered, Unseeded Beach Sands Subjected to Tidal Wetting. J App Microbiol. 2009; 75:1517-1524. 
Highlights

$>$ High concentrations of fecal indictor bacteria and adenovirus found in ponds in rural Bangladesh. > Fecal bacteria and adenovirus in pond water are correlated to human population within $45 \mathrm{~m}$. > Fecal source tracking showed that humans, not cattle, are the primary source of fecal contamination. > Unsanitary latrines were shown to be the primary cause of fecal contamination in ponds. 

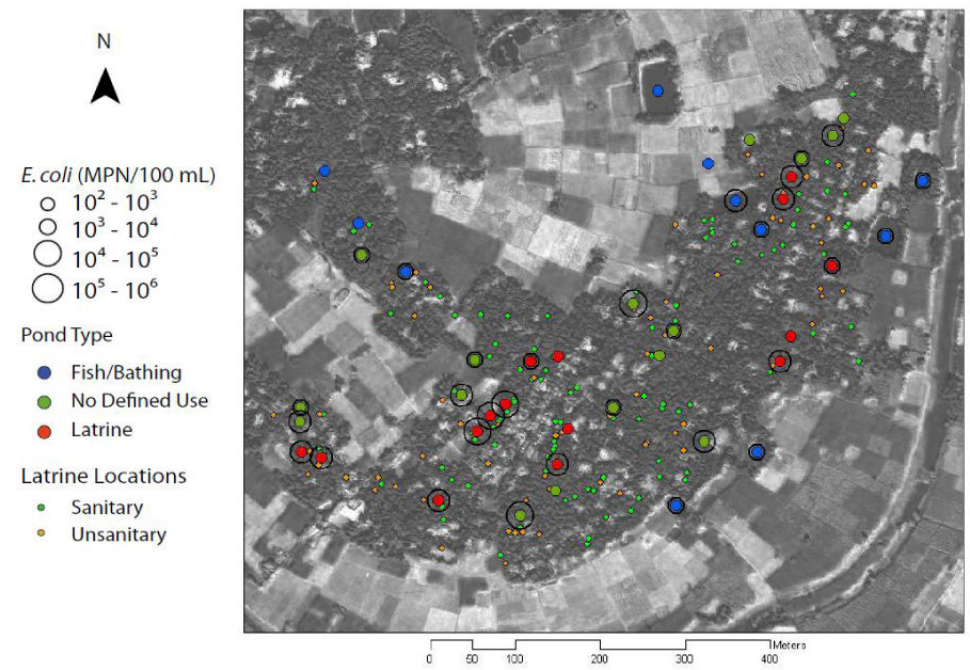

Figure 1.

Concentration of cultured E. coli in each pond classified by pond type with locations of sanitary and unsanitary latrines. IKONOS satellite image taken of the entire region of Araihazar at $1 \mathrm{~m}$ resolution (van Geen et al. 2003). 




Figure 2.

Dissolved oxygen, electrical conductivity, temperature and concentrations (MPN or copies/ $100 \mathrm{~mL}$ ) of three fecal markers in water, from three types of ponds at Site K. The center line represents the median, upper and lower bounds of the box are the $75^{\text {th }}$ and $25^{\text {th }}$ percentile and whiskers represent the extent of the data. Outliers are represented by dots. The number of ponds were 43, consisting of 11 fish/bathing, 16 latrine and 16 ponds with no defined use in each category. The geometric mean detection limit for molecular assays was 8,374 copies/ $100 \mathrm{~mL}$ and is indicated by the dotted line. 


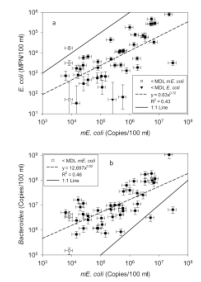

Figure 3.

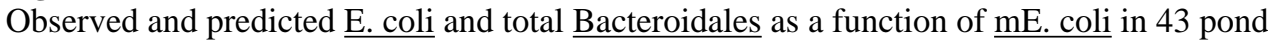
water samples. One non-detect occurred with culturable E. coli and 3 non-detects occurred for $\underline{\mathrm{mE} \text {. coli }}$, but not in the same samples. Total Bacteroidales was detected in every pond water sample. Error bars represent $95 \%$ analytical confidence intervals. Predictive equation is the result of fitting a linear regression model $(\mathrm{y}=\mathrm{mx}+\mathrm{b})$ to $\log _{10}$-transformed concentrations with $\mathrm{R}^{2}$. The $1: 1$ line is shown for comparison $(\mathrm{y}=\mathrm{x})$. 




Figure 4.

Relative amounts of fecal contamination from Human or Bovine sources. Blue circles represent ponds where Human or Bovine Bacteroidales were not detected. 


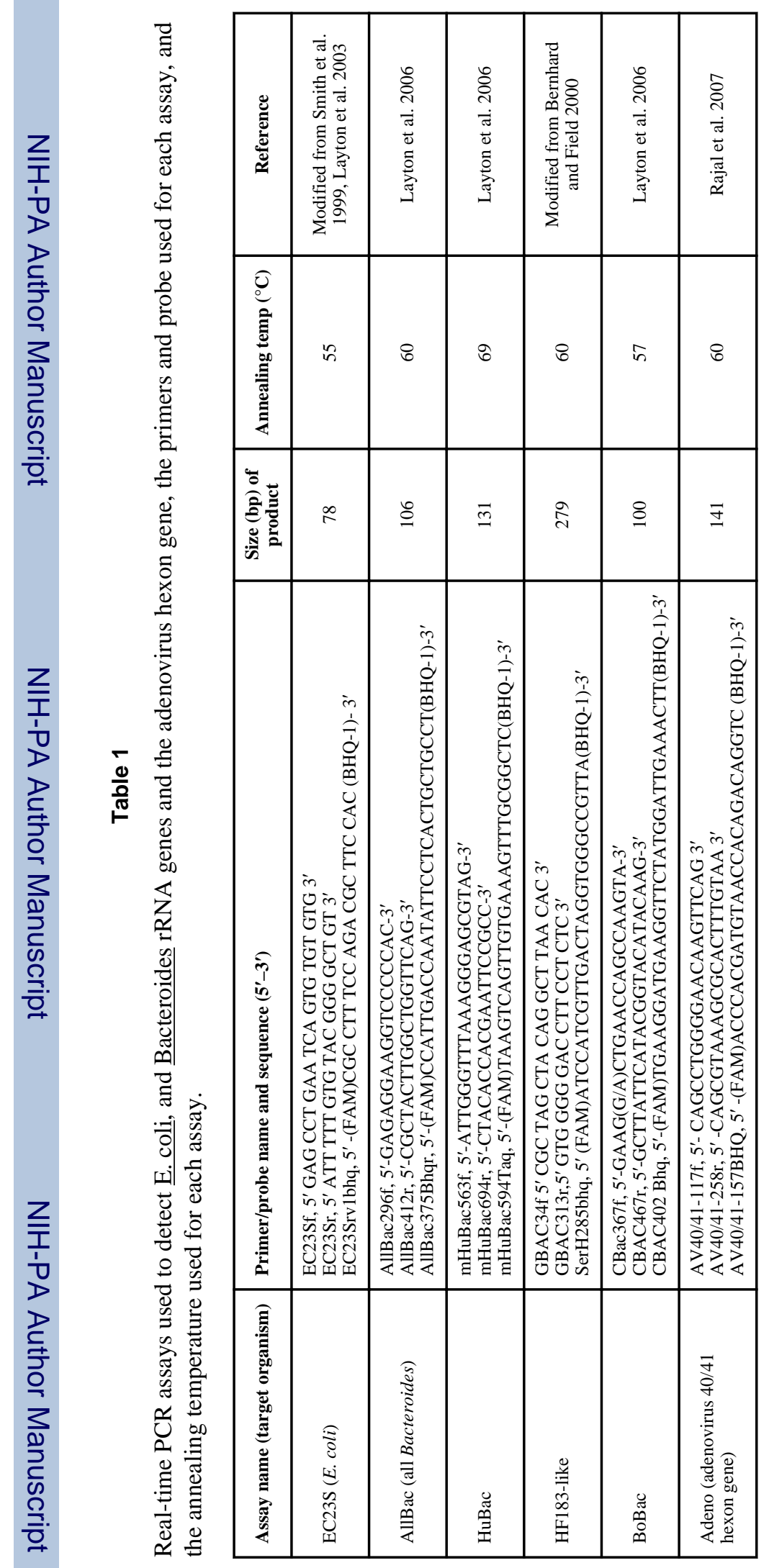


Table 2

Spearman Rank Order correlations of microbial markers with extracted and measured field parameters. Significance in association $\mathrm{p}<0.05$ is indicated by bold.

\begin{tabular}{|c|c|c|c|c|c|c|c|c|c|c|c|c|c|c|c|c|c|}
\hline & & \multicolumn{4}{|c|}{ GIS } & \multicolumn{4}{|c|}{ Pond Basin } & \multicolumn{8}{|c|}{ Measured on Pond Water } \\
\hline & & 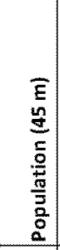 & 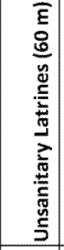 & 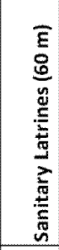 &  & 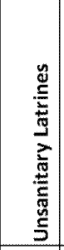 &  &  & 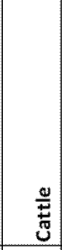 & 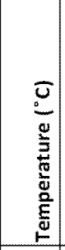 &  & 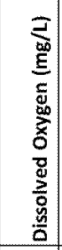 & $\begin{array}{l} \\
\mathrm{z} \\
\mathrm{\omega} \\
\end{array}$ & $\begin{array}{l}\vdots \bar{\vdots} \\
\dot{\mathrm{u}} \\
\mathrm{E}\end{array}$ & 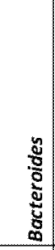 & 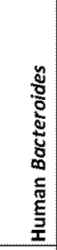 & 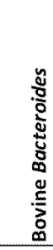 \\
\hline \multirow{3}{*}{ GIS } & Unsanitary Latrines $(60 \mathrm{~m})$ & 0.71 & & & & & & & & & & & & & & & \\
\hline & Sanitary Latrines $(60 \mathrm{~m})$ & 0.52 & 0.27 & & & & & & & & & & & & & & \\
\hline & Total Latrines $(60 \mathrm{~m})$ & 0.77 & 0.90 & 0.60 & & & & & & & & & & & & & \\
\hline \multirow{4}{*}{ Pond Basin } & Unsanitary Latrines & 0.37 & 0.32 & 0.16 & 0.35 & & & & & & & & & & & & \\
\hline & Sanitary Latrines & 0.03 & 0.08 & 0.08 & 0.08 & 0.43 & & & & & & & & & & & \\
\hline & Total Latrines & 0.28 & 0.26 & 0.11 & 0.27 & 0.92 & 0.72 & & & & & & & & & & \\
\hline & Cattle & 0.20 & 0.10 & 0.18 & 0.21 & 0.45 & 0.17 & 0.39 & & & & & & & & & \\
\hline \multirow{9}{*}{$\begin{array}{c}\text { Mea sured } \\
\text { on Pond } \\
\text { Water }\end{array}$} & Temperature $\left({ }^{\circ} \mathrm{C}\right)$ & -0.30 & -0.23 & -0.25 & -0.25 & $\mid-0.21$ & -0.06 & -0.19 & -0.07 & & & & & & & & \\
\hline & Conductivity $(\mathrm{ms} / \mathrm{cm})$ & 0.38 & 0.10 & 0.20 & 0.23 & 0.43 & 0.05 & 0.35 & 0.27 & -0.26 & & & & & & & \\
\hline & Dissolved Oxygen (mg/L) & -0.36 & -0.42 & -0.10 & -0.35 & -0.31 & -0.20 & -0.33 & 0.11 & 0.69 & -0.29 & & & & & & \\
\hline & E. coli & 0.57 & 0.33 & 0.31 & 0.40 & 0.46 & 0.00 & 0.33 & 0.32 & -0.18 & 0.47 & -0.14 & & & & & \\
\hline & mE. coli & 0.46 & 0.30 & 0.16 & 0.37 & 0.37 & -0.25 & 0.18 & 0.40 & -0.04 & 0.49 & -0.08 & 0.69 & & & & \\
\hline & Bacteroides & 0.38 & 0.26 & 0.28 & 0.36 & 0.41 & 0.01 & 0.31 & 0.41 & -0.09 & 0.52 & -0.11 & 0.69 & 0.69 & & & \\
\hline & Human Bacteroides & 0.34 & 0.22 & 0.22 & 0.24 & 0.17 & -0.04 & 0.09 & 0.05 & -0.23 & 0.41 & -0.04 & 0.69 & 0.42 & 0.50 & & \\
\hline & Bovine Bacteroides & 0.36 & 0.11 & 0.27 & 0.21 & 0.19 & -0.05 & 0.10 & 0.05 & -0.06 & 0.41 & -0.04 & 0.70 & 0.53 & 0.47 & 0.63 & \\
\hline & Adenovirus & 0.06 & 0.07 & -0.18 & -0.04 & 0.10 & -0.20 & 0.03 & 0.02 & 0.11 & 0.16 & 0.11 & 0.09 & 0.25 & 0.25 & 0.22 & 0.12 \\
\hline
\end{tabular}

